\title{
CORYPHÆNA HIPPURUS。
}

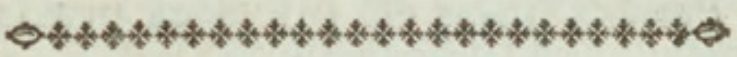

CHARACTER GENERICUS.

Caput maxime truncato-declive. Membrana brancbioftega radiis quinque. Pinna dorfalis longitudine dorfi.

CHARACTER SPECIFICUS, ËC.

CORYPHÆNA THALASSINA, aurantio-gut-i tata, dorfo cæruleo, cauda bifida.

CORYPHÆNA cauda bifida, radiis dorfalibus fexaginta.

$$
\text { Lin. Syft. Nat. p. } 446 .
$$

CORYPHÆNA pinna ani radiis viginti quinque. Bloch. aufl. Fifch 2. p. 143. t. 174.

Generi Coryphænæ, ut plurimum, obtigit infolitus colorum fplendor; cujus variæ fpecies vel ipfis pulcherrimis Labris Zeifque non cedunt, immo etiam nec auratis fulgentiffimifque Cyprinis. Species, quam jam memoravimus, in mari Mediterraneo non raro invenitur; illamque interdum gravi 
errore Delphinis nomine vocaverunt nonnulli. In longitudinem quatuor vel etiam quinque pedum crefcit. Perniciffmus eft pifcis et prædando vitam fuftinet. 


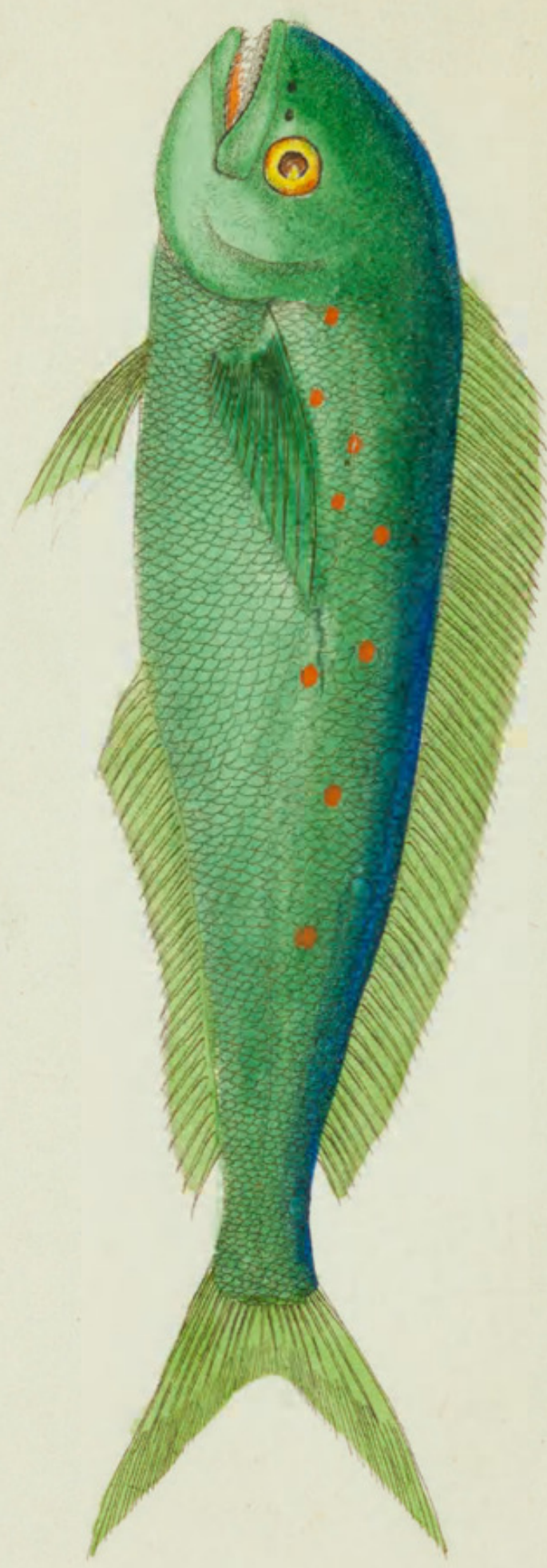


THE

\section{COMMON CORYPH ENA.}

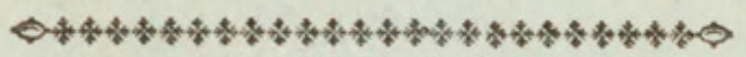

GENERIC CHARACTER.

Head floping fuddenly downwards.

Gill-covers five-rayed.

Dorfal Fin the length of the back.

SPECIFIC CHARACTER, $\Xi^{\circ}$.

SEA-GREEN CORYHÆNA, fpotted with orange, with blue back and forked tail.

The COMMION CORYPHÆNA.

The SEA-GREEN SPOTTED CORYPHENE, popularly called the Dolphin.

The genus Coryphæna is diftinguifhed in general by a more than ufual gaiety of color; many of the fpecies being equal in brilliancy to the richeft of the Labri and Zei, or even to the golden fplendor of fome of the Cyprini. The particular fpecies here reprefented is not unfrequently found in the Mediterranean, and has fometimes been moft erroneouny called by the title of Dolphin. It grows to the length of four, or even five feet. It is extremely fwift and vigorous, and of a predacious nature. 


\section{$2 \mathrm{BHL}$ Biodiversity Heritage Library}

Shaw, George. 1796. "The Common Coryphæna, Coryphæna hippurus [PI. 242]." The Naturalist's Miscellany 7(LXXX), https://doi.org/10.5962/p.310785.

View This Item Online: https://www.biodiversitylibrary.org/item/276356

DOI: https://doi.org/10.5962/p.310785

Permalink: https://www.biodiversitylibrary.org/partpdf/310785

\section{Holding Institution}

Museums Victoria

\section{Sponsored by}

Atlas of Living Australia

\section{Copyright \& Reuse}

Copyright Status: Public domain. The BHL considers that this work is no longer under copyright protection.

This document was created from content at the Biodiversity Heritage Library, the world's largest open access digital library for biodiversity literature and archives. Visit BHL at https://www.biodiversitylibrary.org. 